\title{
PENERAPAN USABILITY TESTING UNTUK PENGUKURAN TINGKAT KEBERGUNAAN WEB MEDIA OF KNOWLEDGE
}

\author{
Alam Supriyatna \\ Prodi : Sistem Informasi \\ Institusi : STIKOM Binaniaga. \\ Email: alamsupriyatna6429@gmail.com
}

\begin{abstract}
PT. Bank Mega Tbk since 2000 already has a Contact Center, which is supported by sophisticated technology. One of the technologies available at the PT Bank Mega Tbk Contact Center is a web-based application called Media of Knowledge, which is one source of information that supports the work of Contact Center staff at PT. Bank Mega Tbk. This study aims to determine the usefulness of the web-based application. Evaluation of the Media of Knowledge application uses the Usability Testing method which consists of the variables Learnability, Efficiency, Memorability, Errors, and Satisfaction. By using the Usability method researchers can find out the usefulness of the Media of Knowledge application at PT Bank Mega Tbk. The results of the measurements are based on the number of employee responses, which shows the memorability variable has the best response, with a value of 3.97 which is in the good category. Then ranked second satisfaction variable with a value of 3.87 which is in the good category. Next in the third rank is the learnability variable with a value of 3.82 which is in the good category. In the fourth rank the error variable with a value of 3.27 which is included in the category is quite good. The efficiency variable is ranked fifth or the last with a value of 2.77 which is in the pretty good category. Based on the value of the evaluation of this research it can be known that the efficiency variable is something that needs to be improved again in the Media of Knowledge application. Overall this Media of Knowledge application has a good level of usefulness.
\end{abstract}

Keywords: Usability Testing, Media of Knowledge, Efficiency

\section{ABSTRAK}

PT. Bank Mega Tbk sejak tahun 2000 sudah memiliki Contact Center, yang di dukung dengan teknologi yang canggih. Salah satu teknologi yang ada pada Contact Center PT Bank Mega Tbk adalah aplikasi berbasis web yang di sebut Media of Knowledge, yang merupakan salah satu sumber informasi yang menunjang pekerjaan staff Contact Center di PT. Bank Mega Tbk. Penelitian ini bertujuan untuk mengetahui tingkat kebergunaan dari aplikasi berbasis web tersebut. Evaluasi terhadap aplikasi Media of Knowledge menggunakan metode Usability Testing yang terdiri dari variabel Learnability, Efficiency, Memorability, Errors, dan Satisfaction. Dengan menggunakan metode Usability peneliti dapat mengetahui tingkat kebergunaan dari aplikasi Media of Knowledge di PT Bank Mega Tbk. Hasil dari pengukuran berdasarkan jumlah respon karyawan, yang menunjukan variabel memorability memiliki respon yang paling baik yaitu dengan nilai 3,97 yang masuk dalam kategori baik. Kemudian di peringkat kedua variabel satisfaction dengan nilai 3,87 yang masuk dalam kategori baik. Selanjutnya di peringkat ketiga variabel learnability dengan nilai 3,82 yang masuk dalam kategori baik. Pada peringkat keempat variabel error dengan nilai 3,27 yang masuk dalam kategori cukup baik. Variabel efficiency peringkat kelima atau yang terakhir dengan nilai 2,77 yang masuk dalam kategori cukup baik. Berdasarkan nilai dari evaluasi penelitian ini dapat di ketahui variabel efficiency menjadi hal yang perlu di tingkatkan kembali dalam aplikasi Media of Knowledge. Secara keseluruhan aplikasi Media of Knowledge ini memiliki tingkat kebergunaan yang baik.

Kata kunci : Usability Testing, Media of Knowledge, Efficiency 


\section{PENDAHULUAN}

\section{A. Latar Belakang}

Berawal dari sebuah usaha milik keluarga bernama PT. Bank Karman yang didirikan pada tahun 1969 dan berkedudukan di Surabaya, selanjutnya pada tahun 1992 berubah nama menjadi PT. Mega Bank dan melakukan relokasi Kantor Pusat ke Jakarta.

Seiring dengan perkembangannya PT. Mega Bank pada tahun 1996 diambil alih oleh PARA GROUP (PT. Para Global Investindo dan PT. Para Rekan Investama) sebuah holding company milik pengusaha nasional - Chairul Tanjung. Selanjutnya PARA GROUP berubah nama menjadi CT Corpora.

Untuk lebih meningkatkan citra PT. Mega Bank, pada bulan Juni 1997 melakukan perubahan logo Bank Mega berupa tulisan huruf M warna biru kuning dengan tujuan bahwa sebagai lembaga keuangan kepercayaan masyarakat, akan lebih mudah dikenal melalui logo perusahaan yang baru tersebut. Pada tahun 2000 dilakukan perubahan nama dari PT. Mega Bank menjadi PT. Bank Mega.

Begitu pula dengan teknologi yang dipakai oleh Bank Mega terus berkembang.Efek perkembangan teknologi dirasakan atau dipengaruhi seluruh aspek kegiatan yang ada di Bank Mega. Salah satu kegiatan yang ikut berkembang bersama teknologi saat ini adalah Call Center. Demi meningkatkan kenyamanan serta kepuasan dalam permasalahan yang dialami setiap nasabah Bank Mega. Call Center Bank Mega membangun dan membeli aplikasi dan sistem dari beberapa Vendor penyedia aplikasi ternama.

Beberapa aplikasi yang dimiliki Call Center Bank Mega berbasis website dan desktop.

Media of Knowledge atau yang biasa dipanggil dengan MOK adalah salah satu aplikasi yang digunakan di Call Center. Media of Knowledge ini adalah sebuah media yang dimana sebagai pusat informasi yang ada di Bank Mega. Promopromo, produk kartu kredit, produk bank, penjadwalan masuk Mega Call Officer, hingga penilaian Mega Call Officer ada dalam Media of Knowledge tersebut.

Melihat banyaknya aplikasi dan sistem yang saat ini telah dibuat dan bahkan dikembangkan oleh para programer serta melihat kebutuhan perusahaan yang membutuhkan aplikasi dalam bentuk website atau desktop. Tentunya menjadi sebuah tuntutan bagi para programer perusahaan untuk mengaplikasikan dan mengukur kebergunaan aplikasi tersebut. Mengukur kebergunaan ini bertujuan untuk menilai apakah layak aplikasi tersebut untuk digunakan atau perlu di perbaiki dan bahkan bisa untuk di kembangkan menjadi sebuah aplikasi yang lebih baik dari yang sebelumnya. Agar para pemimpin perusahaan mengetahui apakah aplikasi tersebut baik. Maka dari itu diperlukannya metode untuk menilai setiap aplikasi dan sistem yang ada di Call Center Bank Mega. 
Dalam pengembangan suatu software atau perangkat lunak, salah satu factor penentu keberhasilan suatu sistem adalah faktor usability. Faktor usability ini menentukan manfaat dari sistem, penerimaan user dan lama waktu penggunaan sistem. Pengukuran usability sistem sangat penting untuk mengetahui tinggi atau rendahnya tingkat kebergunaan suatu sistem. Sistem yang memiliki usability yang tinggi akan digunakan dalam jangka waktu yang lama karena banyak orang merasakan manfaat dari sistem tersebut. Sedangkan sistem yang memiliki usability yang rendah pada akhirnya akan diabaikan oleh pengguna.

Jurnal Eko Saputra yang berjudul "Usability Testing Untuk Mengukur Penggunaan Website Inspektorat Kota Palembang" menjadi referensi penulis dalam menggunakan metode Usability Testing untuk mengukur tingkat kebergunaan website Media of Knowledge.

Melihat hal tersebut penulis melalukan pengukuran pada Media of Knowledge dengan menggunakan metode Usability Testing dengan perhitungan rata-rata atau

Mean. metode Usability Testing menggunakan pertanyaan yang terbagi berdasarkan beberapa kategori pertanyaan yaitu Learnability, Efficiency, Memorability, Errors, dan Satisfaction dan terdiri dari 20 pertanyaan. Beberapa masalah pada aplikasi Media of Knowledge yang teridentifikasi berdasarkan laporan-laporan Mega Call Officer yang tercatat kepada pihak Team Support menjadikan salah satu landasan dari penulis untuk melakukan pengukuran kebergunaan.

\section{B. RUMUSAN MASALAH}

Sebagai media informasi yang dipakai pelaporan dari permasalahan aplikasi ini dalam kegiatan pekerjaan, aplikasi Media of selalu di perhatikan

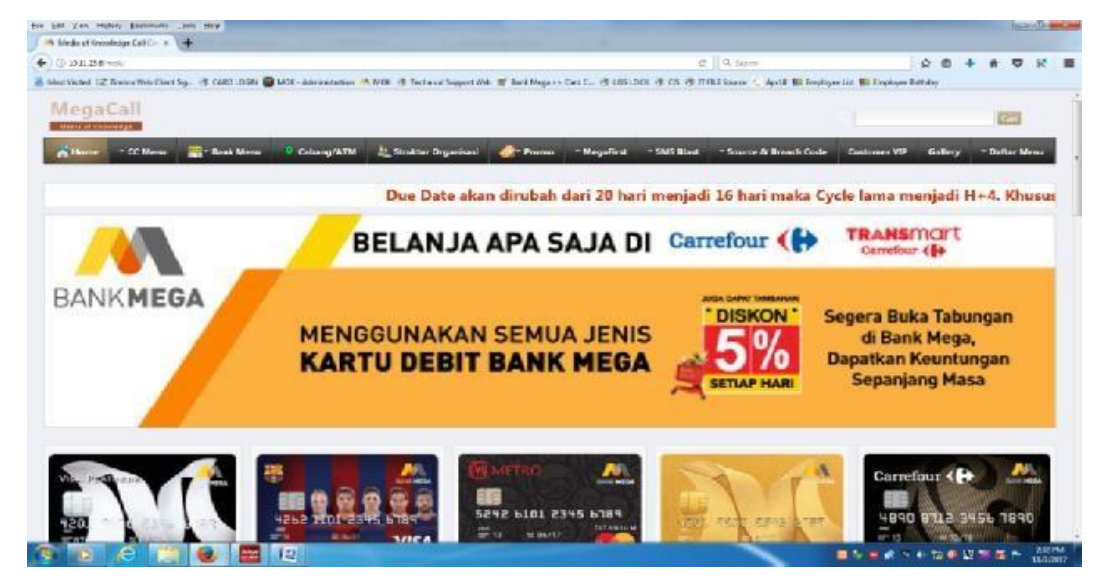

Gambar 1. Aplikasi Media of Knowledge 


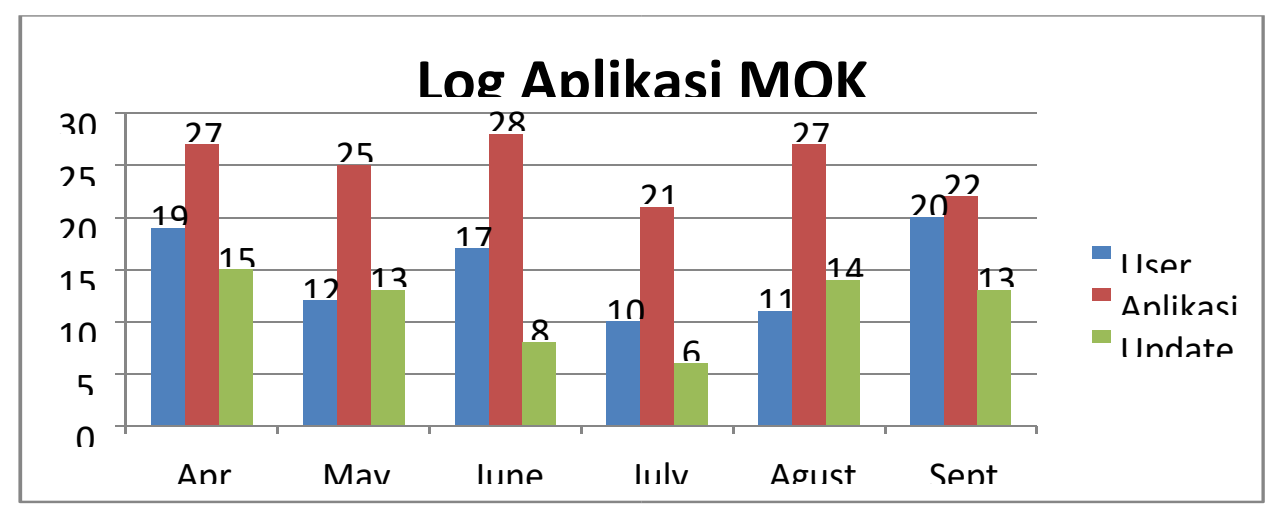

Gambar 2. Log Aplikasi Media of Knowledge

Beberapa masalah pada aplikasi Media of Knowledge yang teridentifikasi berdasarkan laporanlaporan Mega Call Officer yang tercatat pada pihak Team Support menjadikan salah satu landasan dari penulis untuk melakukan pengukuran kebergunaan pada aplikasi tersebut.

Setelah di kelompokan sebelumnya maka didapatkan 3 kategori dari laporanlaporan Mega Call Officer yang ada di Bank Mega. Kategorinya adalah user, aplikasi, dan update. Berdasarkan hasil pengkategorian didapatkan bahwa terbanyak permasalah yang dilaporan berasal dari aplikasi tersebut.

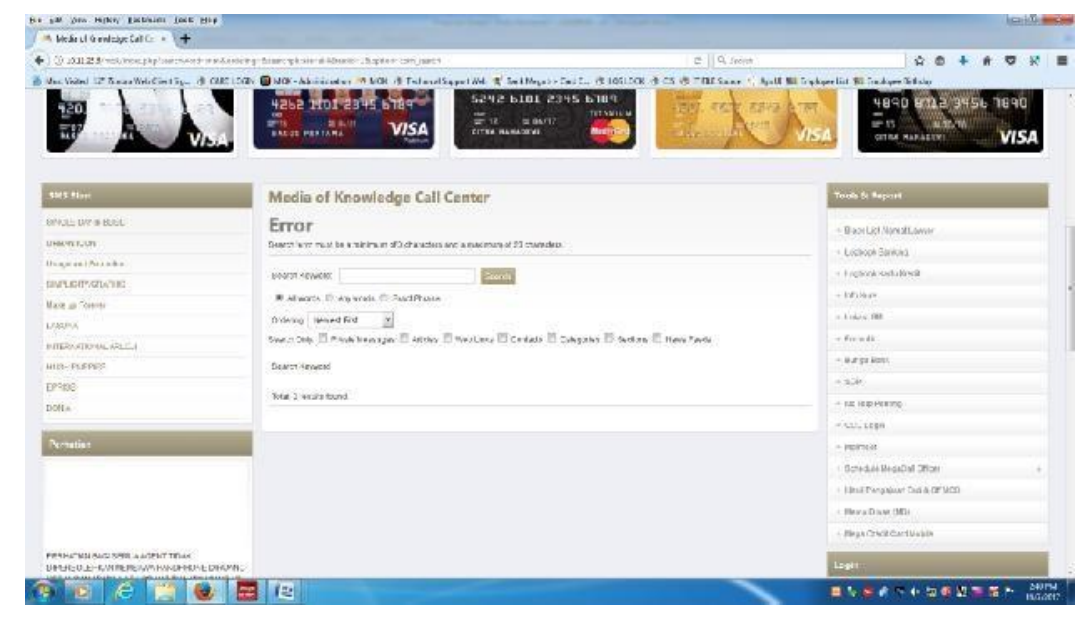

Gambar 3. Error dalam pencarian data

Berdasarkan dari Data yang diperoleh dari Team Support Call Center Bank Mega maka dapat diidentifikasi permasalahannya adalah sebagai berikut :

1. Sulitnya mendapatkan informasi saat pencarian suatu informasi.

2. Beberapa Halaman Website yang dituju tidak ditemukan saat diakses atau error.

Dari pernyataan masalah diatas yang bisa diuraikan sebagai berikut:

1. Belum diketahui tingkat kebergunaan dari aplikasi Media of Knowledge berdasarkan 5 variable yaitu learnability, efficiency, memorability, errors, dan satisfaction.

2. Belum diketahui tingkat kebergunaan dari aplikasi Media of Knowledge.

Pertanyaan penelitian (research question) berdasarkan rumusan masalah diatas yaitu: "Apakah tingkat kebergunaan pada aplikasi Media of Knowledge di Call Center Bank Mega?” 


\section{MAKSUD DAN TUJUAN PENELITIAN}

Maksud dari penelitian ini adalah Untuk menerapkan metode Usability Testing untuk pengukuran tinggkat kebergunaan aplikasi Media of Knowledge.

Tujuan dari penelitian ini adalah :

1. Untuk mengukur tingkat kebergunaan dari aplikasi Media of Knowledge berdasarkan 5 variable yaitu learnability, efficiency, memorability, errors, dan satisfaction.

2. Untuk mengukur tingkat kebergunaan dari aplikasi Media of Knowledge.

D. Kegunaan Dan Manfaat Penelitian

Kegunaan penelitian ini adalah untuk mengetahui tingkat kebergunaan dari aplikasi Media of Knowledge. Manfaat dari penelitian ini adalah:

1. Manfaat Teoritis

Penelitian ini dapat menjadi sumbangan ilmu pengetahuan bagi perkembangan teknologi informasi, terutama dalam melakukan penerapan metode Usability Testing terhadap aplikasi yang digunakan.

2. Manfaat Praktis

Penelitian ini dapat memberikan pemahaman tentang tingkat kebergunaan terhadap aplikasi Media of Knowledge di Call Center Bank Mega.

3. Manfaat Kebijakan

Penelitian ini dapat dijadikan bahan acuan dalam pengembangan aplikasi Media of Knowledge untuk meningkatkan performa aplikasi tersebut.

\section{E. Ruang Lingkup Dan Keterbatasan Penelitian}

Ruang lingkup penelitian ini terbatas pada pengguna aplikasi Media of Knowledge di Call Center Bank Mega yaitu Mega Call Officer. Penelitian ini terbatas hanya pada aplikasi Media of Knowledge untuk mengetahui tingkat kebergunaannya. Penelitian ini menggunakan metode Usability Testing berdasarkan 5 variable yaitu learnability, efficiency, memorability, errors, dan satisfaction.

Penelitian ini memiliki keterbatasan yaitu penyebaran quistioner untuk penelitian ini harus di lakukan didua tempat berbeda dikarenakan Call Center Bank Mega berada didua lokasi yang berbeda dan waktu yang sulit untuk di sesuaikan dengan penempatan tugas.

\section{F. RUANG LINGKUP DAN KETERBATASAN PENELITIAN}

Ruang lingkup penelitian ini terbatas pada pengguna aplikasi Media of Knowledge di Call Center Bank Mega yaitu Mega Call Officer. Penelitian ini terbatas hanya pada aplikasi Media of Knowledge untuk mengetahui tingkat kebergunaannya. Penelitian ini menggunakan metode 
Usability Testing berdasarkan 5 variable yaitu learnability, efficiency, memorability, errors, dan satisfaction.

Penelitian ini memiliki keterbatasan yaitu penyebaran quistioner untuk penelitian ini harus di lakukan didua tempat berbeda dikarenakan Call Center Bank Mega berada didua lokasi yang berbeda dan waktu yang sulit untuk di sesuaikan dengan penempatan tugas.

\section{METODE}

\section{Landasan Teori}

Dalam rangka memperoleh suatu pedoman guna lebih memperdalam masalah, maka perlu dikemukakan suatu landasan teori yang bersifat ilmiah. Dalam landasan teori ini dikemukakan teori yang ada hubungannya dengan materi-materi yang digunakan untuk memecahkan masalah pada penelitian ini.

\section{User Satisfaction}

User satisfaction Menurut (Yamin \& Ramayah, 2011). Kepuasan adalah keadaan subjektif dari kepuasan. Ini adalah pernyataan dimana orang merasa senang dengan pencapaian mereka dengan beberapa usaha. Pada umumnya kepuasan pengguna sering diartikan sebagai perbedaan antara harapan (expectation), dengan kinerja yang dirasakan (perceived performance) dari suatu produk.

Menurut (Armstrong, et al., 2006) kepuasan adalah perasaan seseorang yang dihasilkan dari membandingkan kinerja produk yang dirasakan (atau hasil) dalam kaitannya dengan harapannya. Jadi dapat dikatakan bahwa tingkat kepuasan merupakan fungsi dari perbedaan antara harapan dengan kinerja yang dirasakan. Apabila kinerja dibawah harapan, maka pengguna akan kecewa. Bila kinerja sesuai dengan harapan atau melebihi, pengguna akan puas. Dalam (N \& Dastidar, 2009) disebutkan bahwa kepuasan adalah serangkaian reaksi biasa yang dimiliki pengguna ketika menggunakan website. Website harus menyenangkan untuk digunakan dan dilihat. Persepsi pengguna atas kesenangan mempengaruhi mereka dalam anggapan mudah digunakan, motivasi untuk belajar bagaimana menggunakan website, keyakinan dalam keandalan isi informasi, niat/kemauan di masa mendatang, rekomendasi Kepuasan terhadap website mengacu pada pemenuhan kebutuhan dan ekspektasi konsumen pada website.

Keseluruhan persepsi kepuasan biasanya menghasilkan keseluruhan sikap positif terhadap website (Szymanski and Hise (2000) dalam (Kabadayi \& Gupta, 2011).

Berdasarkan (Byun \& Finnie, 2011), pengukuran tingkat kepuasan pengguna diambil berdasarkan penelitian Spool et al yang meliputi :

a. Physical Fatique : berkenaan dengan kelelahan fisik yang dialami pengguna dalam menggunakan website. 
b. Confusing during the task : mengenai tingkat kebingungan dalam melakukan tugas dalam website.

c. Degree of stress after finding the correct answer : mengenai derajat stress yang dirasakan oleh pengguna setelah menemukan apa yang dicari.

d. Actual speed of tasks : mengenai kecepatan website dalam melakukan tugas yang diminta pengguna.

e. Satisfaction about the quality of information provided: mengenai kepuasan pengguna atas kualitas informasi yang disediakan.

f. Attitude about proceeding to another task after completing a task : mengenai sikap pengguna untuk melakukan tugas lain dalam website.

2. Usability

Menurut Jacob Nielsen (2017), usability adalah atribut kualitas yang menjelaskan atau mengukur seberapa mudah penggunaan suatu antar muka (interface). Kata "usability" juga merujuk pada suatu metode untuk meningkatkan kemudahan pemakaian selama proses desain. Usability Testing diukur dengan lima kriteria, yaitu:

a. Learnability mengukur tingkat kemudahan melakukan tugastugas sederhana ketika pertama kali menemui suatu desain.

b. Efficiency mengukur kecepatan mengerjakan tugas tertentu setelah mempelajari desain tersebut.

c. Memorability melihat seberapa cepat pengguna mendapatkan kembali kecakapan dalam menggunakan desain tersebut ketika kembali setelah beberapa waktu.

d. Errors melihat seberapa banyak kesalahan yang dilakukan pengguna, separah apa kesalahan yang dibuat, dan semudah apa mereka mendapatkan penyelesaian.

e. Satisfaction mengukur tingkat kepuasan dalam menggunakan desain.

\section{Populasi}

Menurut Sugiyono (Panji Nugraha, 2013) populasi adalah wilayah generalisasi yang terdiri dari atas obyek atau subyek yang mempunyai kualitas dan karakteristik tertentu yang ditetapkan oleh peneliti untuk dipelajari dan kemudian ditarik kesimpulannya. Dari penjelasan ahli tersebut, jumlah populasi dalam penelitian ini adalah Megacall Officer yang berjumlah 286 orang sebagai pengguna aplikasi Media of Knowledge.

\section{Sample}

Uji coba dilakukan dengan mengambil sample dari pengguna dari Call Center Bank Mega. Menurut Sugiyono (2014:81) sampel adalah bagian atau jumlah dan karakteristik yang dimiliki oleh populasi tersebut. Bila populasi besar, dan peneliti tidak mungkin mempelajari semua yang ada pada populasi, misal karena keterbatasan dana, tenaga dan waktu, maka 
peneliti akan mengambil sampel dari populasi. Teknik pengambilan sampel yang digunakan adalah probability sampling menggunakan rumus Slovin.

Menurut Sugiyono (2014:82), Probability sampling adalah teknik pengambilan sampel yang memberikan peluang yang sama bagi setiap unsur (anggota) populasi untuk dipilih menjadi anggota sampel. Dari beberapa definisi yang telah dikemukakan dapat disimpulkan bahwa untuk menentukan sampel pengamat akan menggunakan rumus Slovin sebagai berikut:

$$
n=\frac{N}{1+N e^{2}}
$$

\section{Keterangan:}

$\mathrm{n}=$ Ukuran sampel

$\mathrm{N}=$ Ukuran populasi

$\mathrm{e}=$ Kelonggaran ketidak telitian karena kesalahan pengambilan sampel yang dapat ditolerir, $(\mathrm{e}=0,1)$. Populasi yang ada dalam Call Center Bank Mega adalah 286. Berdasarkan rumus Slovin, maka ukuran sample adalah 74 orang.

\section{Kerangka Pemikiran}

Kerangka pemikiran dalam penelitian ini berdasarkan masalah yang akan dipecahkan yang kemudian mendapatkan hasil yang akan diuji kelayakannya. Berikut kerangka pemikiran dalam penelitian ini (Gambar 4.).

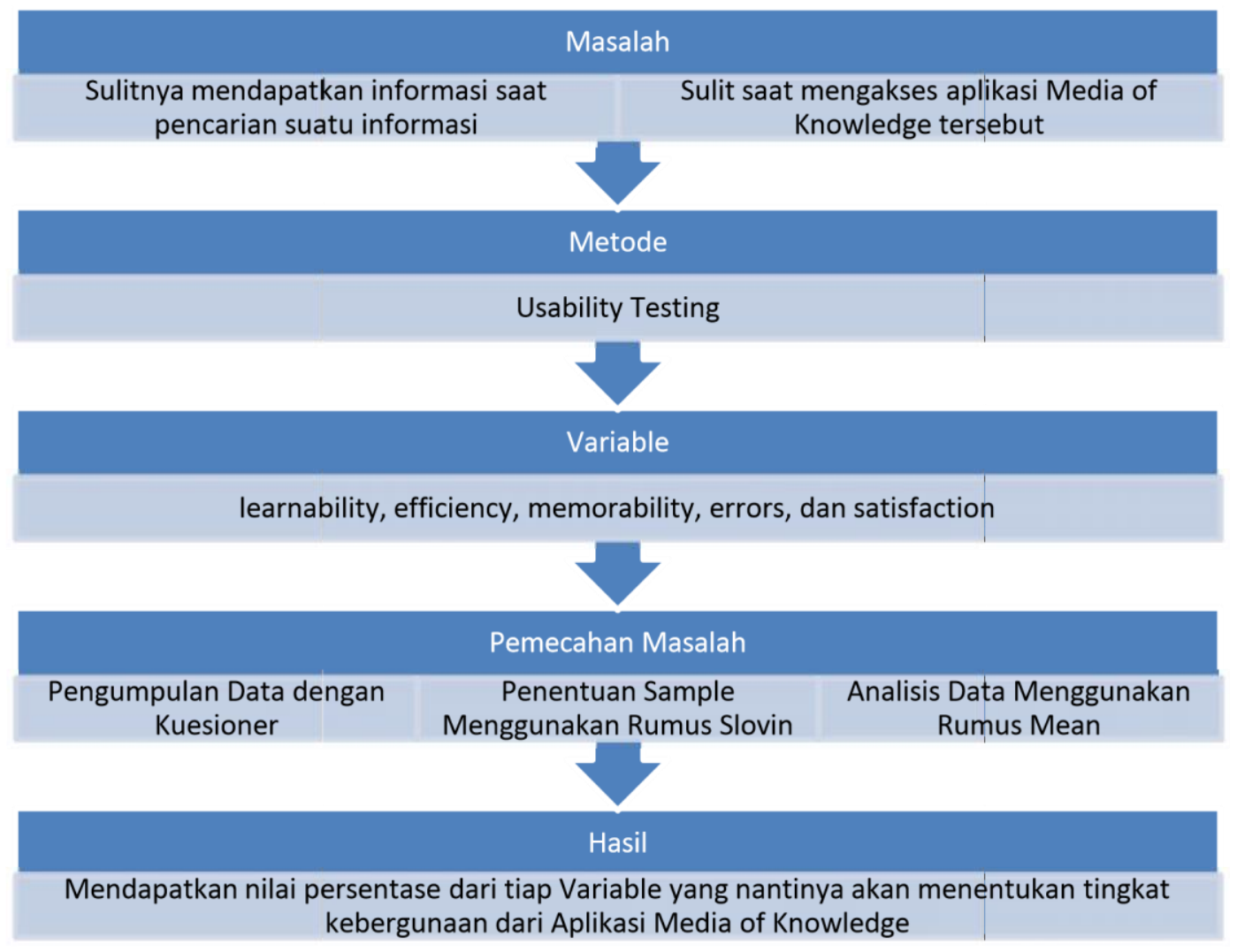

Gambar 4. Kerangka Pemikiran 
Berdasarkan Gambar 4. kerangka pemikiran dimulai dengan masalah yaitu:

1. Mengidentifikasi masalah yaitu Sulitnya mendapatkan informasi saat pencarian suatu informasi dan Halaman Website tidak ditemukan saat mengakses informasi pada aplikasi Media of Knowledge tersebut permasalah ini didapat dari Log Laporan pengguna.

2. Pemilihan metode Usability Testing dirasa tepat karena melihat dari laporan permasalahan yang didapat pengguna.

3. Pengukuran dilakukan berdasarkan 5 variabel dari metode Usability Testing yaitu learnability, efficiency, memorability, errors, dan satisfaction.

4. Kemudian akan diimplementasikan di Call Center Bank Mega dan di olah menggunakan metode Mean

5. Kemudian mendapatkan hasil data yang berupa data hasil survey per pengguna per kategori dari metode.

\section{HASIL DAN PEMBAHASAN}

Hasil kuisioner dari 74 sampel yang mengukur kelayakan aplikasi Media of Knowledge dengan 5 variabel usability adalah sebagai berikut :

Analisa hasil kuesioner

Tabel 3. Hasil rata-rata Variabel Learnability

\begin{tabular}{|l|r|r|r|r|r|}
\hline \multicolumn{7}{|c|}{ Learnability } \\
\hline & SS & ST & RR & TS & STS \\
\hline P1 & 36 & 36 & 2 & 0 & 0 \\
\hline P2 & 2 & 41 & 31 & 0 & 0 \\
\hline P3 & 1 & 42 & 31 & 0 & 0 \\
\hline P4 & 0 & 47 & 27 & 0 & 0 \\
Total & $\mathbf{3 9}$ & $\mathbf{1 6 6}$ & $\mathbf{9 1}$ & $\mathbf{0}$ & $\mathbf{0}$ \\
\hline
\end{tabular}

a. Variabel Learnability pertanyaan variabel Learnability akan di jabarkan pada tabel 4. Jumlah responden yang memilih jawaban Penjelasan dari tabel 3. yaitu:

1. Jumlah jawaban reponden yang memilih nilai 5 sebanyak 39 jawaban

2. Jumlah jawaban reponden yang memilih nilai 4 sebanyak 166 jawaban

3. Jumlah jawaban reponden yang memilih nilai 3 sebanyak 91 jawaban

4. Jumlah jawaban reponden yang memilih nilai 2 sebanyak 0 jawaban

5. Jumlah jawaban reponden yang memilih nilai 1 sebanyak 0 jawaban

Dari hasil analisa variabel Learnability yang dilihat pada tabel 3. paling banyak jumlah jawaban responden dengan kategori setuju sebanyak 166 jawaban dan yang terkecil kategori tidak setuju dan sangat tidak setuju yaitu sebanyak 0 jawaban. 
Tabel 4. Hasil rata-rata Variabel Efficiency

\begin{tabular}{|l|c|c|c|c|c|}
\hline \multicolumn{7}{|c|}{ Efficiency } \\
\cline { 2 - 6 } & SS & ST & RR & TS & STS \\
\hline P1 & 0 & 22 & 36 & 16 & 0 \\
\hline P2 & 0 & 4 & 30 & 35 & 5 \\
\hline P3 & 0 & 17 & 34 & 21 & 2 \\
\hline P4 & 0 & 11 & 30 & 29 & 4 \\
\hline Total & $\mathbf{0}$ & $\mathbf{5 4}$ & $\mathbf{1 3 0}$ & $\mathbf{1 0 1}$ & $\mathbf{1 1}$ \\
\hline
\end{tabular}

b. Variabel Efficiency Jumlah responden yang memilih jawaban pada setiap nilai dari pertanyaan variabel Efficiency akan di jabarkan

1. Jumlah jawaban responden yang memilih nilai 5 sebanyak 0 jawaban

2. Jumlah jawaban reponden yang memilih nilai 4 sebanyak 54 jawaban

3. Jumlah jawaban reponden yang memilih nilai 3 sebanyak 130 jawaban

4. Jumlah jawaban reponden yang memilih nilai 2 sebanyak 101 jawaban

5. Jumlah jawaban reponden yang memilih nilai 1 sebanyak 11 jawaban

Dari hasil analisa variabel Efficiency yang dilihat pada tabel 4 paling banyak jumlah jawaban responden dengan kategori ragu-ragu 130 jawaban dan yang terkecil kategori sangat setuju yaitu sebanyak 0 jawaban

Tabel 5 Hasil rata-rata Variabel Memorability

\begin{tabular}{|l|r|r|r|r|r|}
\hline \multicolumn{7}{|c|}{ Memorability } \\
\cline { 2 - 6 } \multicolumn{1}{|c|}{ SS } & ST & \multicolumn{1}{|c|}{ RR } & TS & STS \\
\hline P1 & 19 & 37 & 18 & 0 & 0 \\
\hline P2 & 16 & 38 & 20 & 0 & 0 \\
\hline P3 & 17 & 36 & 21 & 0 & 0 \\
\hline P4 & 18 & 35 & 21 & 0 & 0 \\
\hline Total & 70 & 146 & 80 & 0 & 0 \\
\hline
\end{tabular}

c. Variabel Memorability Jumlah responden yang memilih jawaban pada setiap nilai dari pertanyaan variabel Memorability akan di jabarkan pada tabel 5. jawaban Penjelasan dari tabel 6. yaitu:

1. Jumlah jawaban reponden yang memilih nilai 5 sebanyak 70 jawaban

2. Jumlah jawaban reponden yang memilih nilai 4 sebanyak 146 jawaban

3. Jumlah jawaban reponden yang memilih nilai 3 sebanyak 80 jawaban

4. Jumlah jawaban reponden yang memilih nilai 2 sebanyak 0 jawaban 
5. Jumlah jawaban reponden yang memilih nilai 1 sebanyak 0 jawaban

Dari hasil analisa variabel Memorability yang dilihat pada tabel 5. paling banyak jumlah jawaban responden dengan kategori setuju 146 jawaban dan yang terkecil kategori tidak setuju dan sangat tidak setuju yaitu sebanyak 0 jawaban

Tabel 7. Hasil rata-rata Variabel Errors

\begin{tabular}{|l|r|r|r|r|r|}
\hline \multicolumn{7}{|c|}{ Errors } \\
\hline & SS & ST & RR & TS & STS \\
\hline P1 & 9 & 20 & 31 & 12 & 2 \\
\hline P2 & 4 & 25 & 30 & 14 & 1 \\
\hline P3 & 4 & 25 & 32 & 11 & 2 \\
\hline P4 & 5 & 25 & 33 & 10 & 1 \\
\hline Total & 22 & 95 & 126 & 47 & 6 \\
\hline
\end{tabular}

d. Variabel Errors Jumlah responden yang memilih jawaban pada setiap nilai dari pertanyaan variabel Errors akan di jabarkan pada tabel 6. Penjelasan dari tabel 6. yaitu:

1. Jumlah jawaban reponden yang memilih nilai 5 sebanyak 22 jawaban

2. Jumlah jawaban reponden yang memilih nilai 4 sebanyak 95 jawaban

3. Jumlah jawaban reponden yang memilih nilai 3 sebanyak 126 jawaban

4. Jumlah jawaban reponden yang memilih nilai 2 sebanyak 47 jawaban

5. Jumlah jawaban reponden yang memilih nilai 1 sebanyak 6 jawaban

Dari hasil analisa variabel Errors yang dilihat pada tabel 6. paling banyak jumlah jawaban responden dengan kategori ragu-ragu 126 jawaban dan yang terkecil kategori sangat tidak setuju yaitu sebanyak

Tabel 8. Hasil rata-rata Variabel Satisfaction

\begin{tabular}{|l|r|r|r|r|r|}
\hline \multicolumn{7}{|c|}{ Satisfaction } \\
\hline & SS & ST & \multicolumn{1}{|c|}{ RR } & TS & STS \\
\hline P1 & 20 & 32 & 22 & 0 & 0 \\
\hline P2 & 14 & 32 & 28 & 0 & 0 \\
\hline P3 & 15 & 31 & 28 & 0 & 0 \\
\hline P4 & 14 & 38 & 22 & 0 & 0 \\
Total & 63 & 133 & 100 & 0 & 0 \\
\hline
\end{tabular}

e. Variabel Satisfaction Jumlah responden yang memilih jawaban pada setiap nilai dari pertanyaan variabel Satisfaction akan di jabarkan pada tabel 7. Penjelasan dari tabel 8. yaitu: 
1. Jumlah jawaban reponden yang memilih nilai 5 sebanyak 63 jawaban

2. Jumlah jawaban reponden yang memilih nilai 4 sebanyak 133 jawaban

3. Jumlah jawaban reponden yang memilih nilai 3 sebanyak 100 jawaban

4. Jumlah jawaban reponden yang memilih nilai 2 sebanyak 0 jawaban

5. Jumlah jawaban reponden yang memilih nilai 1 sebanyak 0 jawaban

Dari hasil analisa variabel Satisfaction yang dilihat pada tabel 7. paling banyak jumlah jawaban responden dengan kategori setuju 133 jawaban dan yang terkecil kategori tidak setuju dan sangat tidak setuju yaitu sebanyak 0 jawaban

\section{PEMBAHASAN}

\section{Analisis Data}

Untuk mengukur kelayakan aplikasi penulis menggunakan metode Mean. Analisis data mempunyai gradasi dari sangat positif menggunakan skor skala 1-5 sampai sangat negatif. Dengan sebagaimana ditunjukkan pada tabel 8. demikian pada penelitian ini menggunakan metode statistic Mean (rata-rata). Mean adalah sebuah rata-rata dari data yang diperoleh berupa angka. Mean adalah "Jumlah nilai-nilai dibagi dengan jumlah individu" (Sutrisno Hadi; 1998). Perhitungan dengan mean ini digunakan untuk mendapatkan nilai pemetaan dari setiap komponen Usability Testing, data yang dihitung adalah data hasil kuesioner yang diisi oleh 74 responden yang merupakan staff Call Center Bank Mega.

Rumus rata-rata

$$
\bar{X}=\frac{\sum X}{n}
$$

Tabel 9. Bobot Jawaban

\begin{tabular}{|c|c|c|c|}
\hline NO & Jawaban & Kode & Nilai \\
\hline 1 & Sangat Setuju & SS & 5 \\
\hline 2 & Setuju & ST & 4 \\
\hline 3 & Ragu-Ragu & RR & 3 \\
\hline 4 & Tidak Setuju & TS & 2 \\
\hline 5 & Sangat Tidak Setuju & STS & 1 \\
\hline
\end{tabular}

Adapun untuk mengetahui panjang interval menggunakan rumus sebagai berikut :

Interval $=($ skor tertinggi - skor terendah $) /$ jumlah kriteria

$\mathrm{I}=(\mathrm{Skt}-\mathrm{Skr}) / \mathrm{v}$ 
$\mathrm{I}=(5-1) / 5=0.8$

Keterangan:

I= Panjang kelas interval

Skt $=$ Skor tertinggi

Skr $=$ Skor terendah

$\mathrm{V}=$ Jumlah kriteria

Panjang kelas interval 0,8 tersebut dibuatkan jarak penilaian untuk mengetahui nilai ratarata yang diberikan oleh responden terhadap setiap unsur pertanyaan yang diberikan. Adapun untuk penilaian kelas interval dapat dilihat pada tabel 9. berikut :

Tabel 10. Interval kriteria penilaian

\begin{tabular}{|c|c|c|}
\hline Kuadran & Kelas Interval & Kriteria Penilaian \\
\hline V & $4,21-5,00$ & Sangat Baik \\
\hline IV & $3,41-4,20$ & Baik \\
\hline III & $2,61-3,40$ & Cukup Baik \\
\hline II & $1,81-2,60$ & Kurang \\
\hline I & $1,00-1,80$ & Sangat Kurang \\
\hline
\end{tabular}

Dari hasil perihitung rata-rat dari variable usability didapatlah nilai-nilai pada tabel $\mathbf{1 0}$ berikut :

Tabel 11. Nilai rata-rata variable Usability

\begin{tabular}{|r|l|c|l|} 
No & Variabel & Rata-Rata & Kategori \\
\hline 1 & Learnability & 3.82 & Baik \\
\hline 2 & Efficiency & 2.77 & Cukup Baik \\
\hline 3 & Memorability & 3.97 & Baik \\
\hline 4 & Error & 3.27 & Cukup Baik \\
\hline 5 & Satisfaction & 3.87 & Baik \\
\hline & Mean & $\mathbf{3 . 4 5}$ & Baik \\
\hline
\end{tabular}

Dari hasil perhitungan pada Tabel 10, dapat dibuat grafik pemetataan tingkat kebergunaan aplikasi web Media of Knowledge seperti pada gambar 5. 


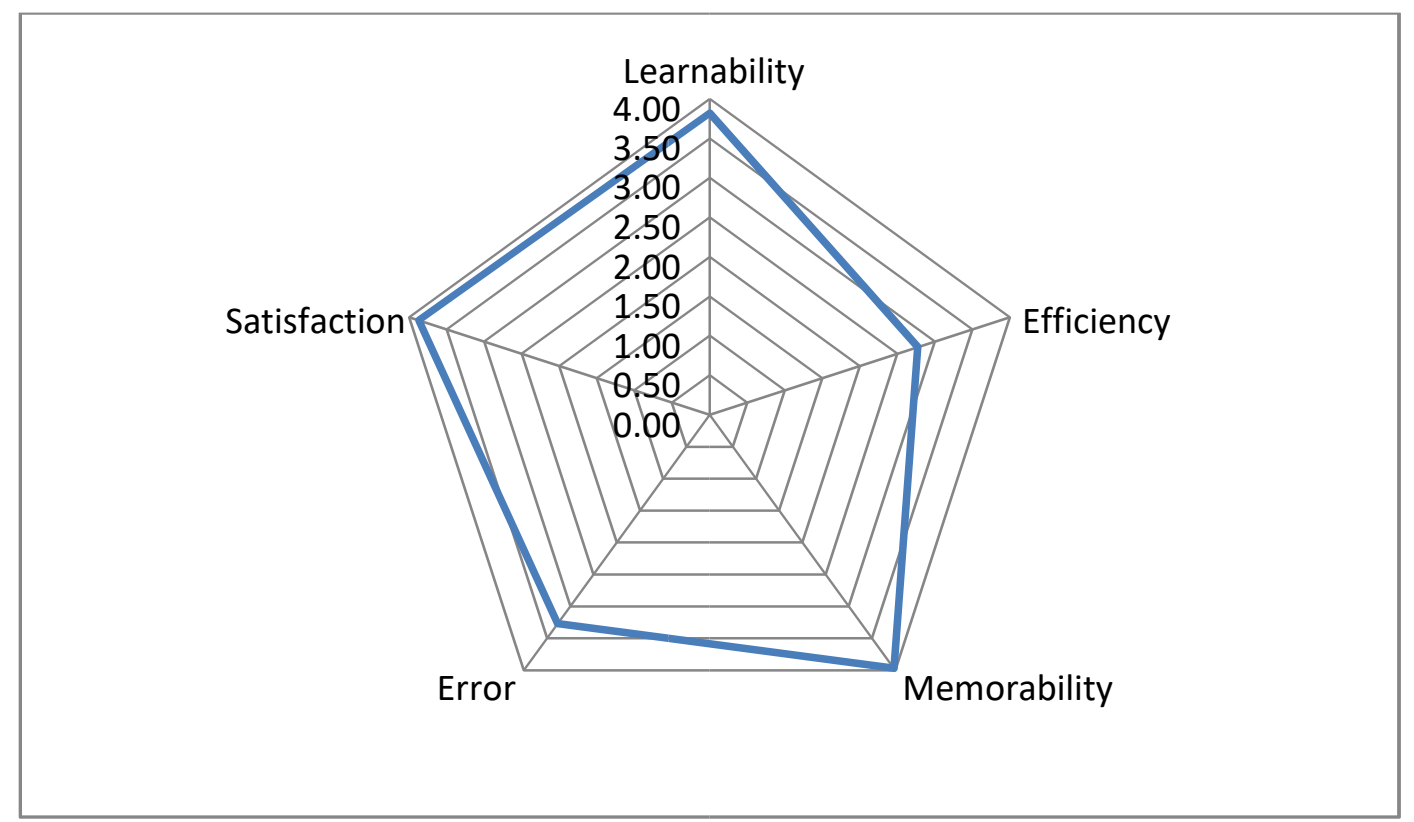

Gambar 5. Grafik pemetaan tingkat kebergunaan web Media of Knowledge

\section{KESIMPULAN DAN SARAN}

\section{Kesimpulan}

Dengan adanya pendekatan Usability yang terdiri dari variabel learnability, efficiency, memorability, error dan satisfaction dapat diketahui kebergunaan aplikasi web Media of Knowledge.

Berdasarkan hasil penelitian, maka dapat disimpulkan beberapa hal sebagai berikut:

1. Hasil pengukuran pemetaan kebergunaan aplikasi web Media of Knowledge berdasarkan variabel learnability dengan jumlah responden sebanyak 74 orang mempunyai nilai rata-rata yaitu 3,82 yang berarti baik.

2. Hasil pengukuran pemetaan kebergunaan aplikasi web Media of Knowledge berdasarkan variabel efficiency dengan jumlah responden sebanyak 74 orang mempunyai nilai rata-rata yaitu 2,77 yang berarti cukup baik.

3. Hasil pengukuran pemetaan kebergunaan aplikasi web Media of Knowledge berdasarkan variabel memorability dengan jumlah responden sebanyak 74 orang mempunyai nilai rata-rata yaitu 3,97 yang berarti baik.

4. Hasil pengukuran pemetaan kebergunaan aplikasi web Media of Knowledge berdasarkan variabel error dengan jumlah responden sebanyak 74 orang mempunyai nilai rata-rata yaitu 3,27 yang berarti cukup baik.

5. Hasil pengukuran pemetaan kebergunaan aplikasi web Media of Knowledge berdasarkan variabel satisfaction dengan jumlah responden sebanyak 74 orang mempunyai nilai rata-rata yaitu 3,87 yang berarti baik. 
6. Secara keseluruhaan hasil perhitungan mean dari semua variabel menghasilkan nilai 3.45 yang menyatakan bahwa aplikasi web Media of Knowledge baik.

\section{Saran}

1. Berdasarkan hasil analisa, pada variable Efficiency dan Error samasama dalam kategori cukup baik, tetapi jika dilihat kembali dari nilai mean yang diperoleh variable Efficiency yang paling kecil. Disarankan untuk aplikasi web Media of Knowledge ini ditingkatkan kembali nilai efficiency-nya.

2. Untuk penelitian selanjutnya, penulis memberikan saran untuk menggunakan pengujian dengan metode usability Webqual dengan pengaruh nilai usability dengan aktifitas karyawan dalam bekerja.

\section{DAFTAR PUSTAKA}

Abdurrahman Sidik, Hafiz Aziz Ahmad, Andar Bagus Sriwarno (2017), Studi Faktor Usability Pada Desain Layout Website Berita Mobile Indonesia, (Seminar Nasional Teknologi Informasi dan Multimedia, 2017)

Arikunto, Suharsimi. (1998). Manajemen Penelitian (Rineka Cipta), Jakarta.

Armstrong, et al, 2006. kepuasan adalah perasaan seseorang yang dihasilkan dari membandingkan kinerja produk yang dirasakan (atau hasil) dalam kaitannya dengan harapannya.

Byun \& Finnie, 2011. pengukuran tingkat kepuasan pengguna diambil berdasarkan penelitian Spool et al.

Definisi Uji validitas dan reliabilitas [online]. Ada di http://qmc.binus.ac.id/2014/11/01/u-j-i-v-a-1id-i-t-a-s-d-a-n-u-j-i-r-e-1-i-a-b-i-l-i-t-a-s [Diakses tanggal 10-11-2017]

Eko Saputra, Zainal Mazalisa, Ria Andryani (2014) Usability Testing Untuk Mengukur Penggunaan Website Inspektorat Kota Palembang, (Universitas Bina Darma Palembang, 2014)

J. Nielsen. 2012. Usability 101:Introduction to Usability [online]. Ada di: https://www.nngroup.com/articles/usability-101-introduction-to-usability/ [diakses tanggal 20 Agustus 2017].

Kabadayi, S. \& Gupta, R., (2011). Managing motives and design to influence web site revisits. Journal of Research in Interactive Marketing, V (2/3), pp. 153-169.

N, S.P. \& Dastidar, S. G., (2009). Impact of the Factors Influencing Website Usability on User Satisfaction. The IUP Jurnal of Management Research, VIII (12), pp. 55-66.

Ni Luh Ayu Kartika Yuniastari Sarja (2016), Analisis Pengukuran Faktor Usability Sistem Informasi Konferensi Nasional Sistem Dan Informatika Stikom Bali, (Seminar Nasional Teknologi Informasi dan Multimedia, 2016)

Pressman, R.S. (2010), Software Engineering : a practitioner's approach, McGraw-Hill, New York, 
68.

Sudijono, Anas. (2008). Pengantar Statistika Pendidikan. Jakarta: Rasa Grafindo Persada.

Sugiyono, (2012). Metode Penelitian Kuantitatif, Kualitatif, dan Kombinasi (Mixed Methods). Bandung.

Sugiyono. (2014). Metode Penelitian Pendidikan Pendekatan Kuantitatif, Kualitatif Dan R\&D. Bandung: Alfabeta.

Sugiyono. (2015). Metode Penelitian Pendidikan (Pendekatan Kuantitatif, Kualitatif dan R\&D). Penerbit CV. Alfabeta: Bandung.

Suskamiyadi, Yani Nurhadryani, Heru Sukoco (2014), Pengembangan dan Uji Usability Sistem Informasi Manajemen Pemantauan Kehadiran dan Nilai Ujian Siswa (Jurnal \& Ilmu Komputer Agri-Informatika, 2014)

Sutrisno Hadi. (1998). Analisis Regresi. Yogyakarta: Gadjah Mada University Press.

Wahyu Hidayat, A. Yani Ranius, Usman Ependi (2014) Penerapan Metode Usability Testing

Pada Evaluasi Situs Web Pemerintahan Kota Prabumulih, (Jurnal Teknik Informatika, 2014) 